Revista Brasileira de Meteorologia, v.26, n.4, 503 - 514, 2011

\title{
A CUT-OFF LOW IN SOUTHERN SOUTH AMERICA: DYNAMIC AND THERMODYNAMIC PROCESSES
}

\author{
ALEJANDRO ANIBAL GODOY ${ }^{1,2}$, NORMA EDIT POSSIA ${ }^{1,2}$, CLAUDIA MARCELA CAMPETELLA \\ 1,2 AND YANINA GARCÍA SKABAR ${ }^{3,4}$
}

\author{
${ }^{1}$ Departamento de Ciencias de la Atmósfera y los Océanos, FCEN - UBA \\ ${ }^{2}$ Centro de Investigaciones del Mar y la Atmósfera, CONICET - UBA \\ ${ }^{3}$ Servicio Meteorológico Nacional, Argentina \\ ${ }^{4}$ Cátedra de Climatología y Fenología Agrícolas, FA - UBA \\ Buenos Aires, Argentina
}

godoy@cima.fcen.uba.ar, possia@cima.fcen.uba.ar, claudiac@cima.fcen.uba.ar, yanina@smn.gov.ar

Recived December 2009 - Accept May 2011

\begin{abstract}
The dynamic and thermodynamic processes involved in the life cycle of a cutoff low occurred in March 2007 are studied. These processes are analyzed using the vorticity and thermodynamic equations and a set of analyses generated with the BRAMS model.

The main processes that explain the segregation of the subtropical part of the trough are the horizontal advection of cyclonic vorticity at high levels and warm horizontal advection at middle levels, both over the Pacific Ocean extending south to the Patagonia region, building the ridge located upstream of the trough. Increased intensity of the upper level low pressure system is mainly explained by intensification of the ridges down and upstream. The divergence effect is opposed to the horizontal advection of vorticity which explains the stagnation of the cut-off low windward of the Andes. The decay stage is dominated by warm vertical advection. Assuming the conservation of potential vorticity the analysis of parcel trajectories, allowed detecting the entrance of stratospheric air to middle levels of the lower troposphere around the cut-off low. Keywords: cut-off lows life cycle, physical processes

RESUMO: UM CASO DE VÓRTICE CICLONICO DESPRENDIDO EM ALTOS NÍVEIS NO SUL DA AMÉRICA DO SUL: PROCESSOS DINÂMICOS E TERMODINÂMICOS

Neste trabalho foram estudados os processos dinâmicos e termodinâmicos que envolvem o ciclo de vida de um caso de vórtice ciclônico desprendido em altos níveis, que ocorreu em março de 2007. Tais processos são analisados através dos termos das equações de vorticidade e termodinâmica usando um conjunto de análises geradas com o modelo BRAMS.

Os principais processos que explicam o desprendimento da parte subtropical de um cavado são a advecção horizontal da vorticidade anticiclonica em níveis altos e a advecção horizontal de ar quente em níveis médios, ambas sobre o sul do Oceano Pacífico e estendendo-se em direção a região Patagônica, aprofundando a crista localizada corrente acima do cavado. A continuidade do aprofundamento desta crista, juntamente com a crista localizada corrente abaixo do cavado são as responsáveis da intensificação do sistema de baixa pressão. O efeito da divergência se opõe a advecção horizontal da vorticidade, e isso explica a situação estacionaria da baixa desprendida a barlavento da Cordilheira dos Andes. A fase de decaimento é dominada pela advecção vertical de ar quente.

A análise das trajetórias das parcelas, considerando a conservação da vorticidade potencial, permitiu observar a entrada de ar estratosférico até os níveis médios da troposfera, em torno do vórtice ciclônico desprendido em altos níveis.

Palavras-Chave: vórtice ciclônico desprendido, ciclo de vida, processos dinâmicos e termodinâmicos .
\end{abstract}




\section{INTRODUCTION}

Cut-off lows (COLs) are synoptic scale phenomena that affect southern South America and are able of producing significant weather phenomena both in the Cordillera region (snowfall, blizzard) and in the plains (heavy rainfall, strong winds). Quispe and Avalos (2006) analyzed a COL event that caused heavy snowfall in the south of Peru, where huge losses of crops, livestock and homes were recorded. Pizarro and Montecinos (2000) found that COLs located close to the coast of Chile contributed by $5 \%$ to $10 \%$ to annual rainfall over Chile between $26^{\circ}$ and $36^{\circ} \mathrm{S}$. Campetella et al (2009) found that over $50 \%$ of rainfall in central western Argentina was associated with the occurrence of COLs. Funatsu et al (2004) showed that COLs could be precursors of cyclogenesis over southeastern South America. Godoy et al (2011) presented a detailed description of the COL lifecycle that occurred from 24 March to 2 April 2007 over the coast of Chile and its links with significant weather events in southern South America.

Case studies of COLs reveal that different processes are involved in the lifecycle stages of these systems. Bell and Bosart (1993) found that the strengthening of a ridge and the propagation of a short-wave trough associated with high potential vorticity values in the upper troposphere explained the cut-off of the low pressure system from its polar source. In a case study, Campetella and Possia (2007) found that during the cut-off stage, strong cold advection at low levels over the eastern side of the migratory anticyclone contributed to the deepening of a trough. Other studies agree that the release of latent heat by condensation causes diabatic effects to prevail during the decay stage (Sakamoto and Takahashi, 2005; Garreaud and Fuenzalida, 2007). The physical processes involved in the cut-off and decay stages of the COLs, as well as their geographic location, play a major role in the duration, intensity and COL phase velocity.

On the other hand, COLs and upper level fronts cause tropopause folding and troposphere-stratosphere exchange of gases (Rondanelli et al, 2002), which is of interest because big concentrations of some stratospheric gases may be harmful to humans (ozone, for example). The numerical simulation by Cox et al. (1997) of a stratospheric intrusion associated with a COL in the northern hemisphere was used by the authors to study the location of the tropopause within and beyond the COL system using different methods. The vertical gradient of temperature, static stability, potential vorticity and specific humidity were used to determine the trajectory of stratospheric air and its location in the troposphere. In this particular case, specific humidity and potential vorticity showed a tongue of stratospheric air that reached down to $2 \mathrm{~km}$ above the earth surface.
The main goal of this paper is to advance the knowledge of the physical and dynamic mechanisms that govern the lifecycle of COLs in South America, by analyzing a case study. The complete description of the lifecycle of the COL that occurred from 26 March to 2 April 2007 and significant related weather phenomena were described in Godoy et al (2011).

\section{DATA AND METHODOLOGY}

To increase the temporal resolution of the meteorological variables, downscaling was performed through a numerical simulation with the Brazilian Regional Atmospheric Modeling System (BRAMS), version 3.2. Hereinafter the set of downscaled analyses will be referred to as BRAMS-40. An overall description of BRAMS can be found in Freitas et al (2009) and at http://brams.cptec.inpe.br. This model has been used to generate analysis sets with satisfactory results in the region (Borque et al, 2010; García Skabar and Nicolini 2009, Nicolini and García Skabar, 2010).

To generate the set of BRAMS- 40 analyses, the model was set as follows: vertical coordinate sigma-Z (Tripoli and Cotton, 1982), with 39 vertical levels in the atmosphere -which reach about $24 \mathrm{~km}$ altitude- and horizontal resolution of $40 \mathrm{~km}$. Grell's deep convection (Grell, 1993) with Grell's closure (Grell and Devenyi, 2002) and shallow convection (Souza and Silva, 2002) parameterizations were activated. A "bulk water" scheme was applied for the microphysics with seven different species. Vertical turbulence was parameterized as in Mellor and Yamada (1982), horizontal turbulence as in Smagorinsky (1963) and radiation as in Chen and Cotton (1983). Other data used in the model include daily soil moisture -provided by the University of Sao Paulo (USP)- weekly sea surface temperature - provided by NCEP (National Centers for Environmental Prediction) (Reynolds et al, 2002)- as well as topography and land use with a resolution of $1 \mathrm{~km}$, and soil type with $5 \mathrm{~km}$ resolution.

The simulation started on 25 March 2007 and lasted 8 days. Initial and boundary conditions were the operational analyses of the NCEP's Global Data Assimilation System (GDAS), with a horizontal resolution of $1^{\circ}, 26$ vertical levels and temporal resolution of 6 hours. BRAMS- 40 analyses were obtained with horizontal resolution of $40 \mathrm{~km}$ and temporal resolution of 1 hour. The fields generated by the BRAMS model were adjusted to GDAS analyses every 6 hours applying a nudging technique in the whole domain.

Dynamic processes were analyzed using the vorticity equation for the free atmosphere in isobaric coordinates:

$$
\underbrace{\frac{\partial \zeta}{\partial t}}_{L C V}=\underbrace{-\delta(\zeta+f)}_{\mathbb{D}} \underbrace{-V_{H} \nabla_{p}}_{H V A} \underbrace{\zeta-v \beta-\omega \frac{\partial \zeta}{\partial p}-\nabla_{p} \omega \times \frac{\partial V_{H}}{\partial p}}_{\text {LOT }}
$$


where $\zeta$ vertical component of the relative vorticity, $V_{H}$ horizontal wind, $V_{p}$ differential nabla operator at constant pressure, $\omega$ vertical velocity of the isobaric system, $\delta$ divergence of horizontal wind, $f$ Coriolis parameter, $\beta$ Rossby parameter, $v$ meridional wind component, LCV: local change of vorticity, DT: divergence term, HVA: horizontal vorticity advection, LOT: lower order terms representing the sum of terrestrial vorticity advection, vertical vorticity advection and tilting.

The following expression of the thermodynamic equation was used:

$$
\underbrace{\frac{\partial \theta}{\partial t}}_{L V T}=\underbrace{-V_{H} \cdot \nabla_{P} \Theta}_{H A T} \underbrace{-\omega \frac{\partial \theta}{\partial p}}_{V A T} \underbrace{+\frac{\theta}{C_{p} T} \frac{\delta Q}{d t}}_{D H}
$$

where $\theta$ is the potential temperature, $\mathrm{T}$ is the absolute temperature and $\delta \mathrm{Q} / \mathrm{dt}$ is the inexact heat differential, LVT: local variation of potential temperature, HAT: horizontal advection of potential temperature, VAT: vertical advection of potential temperature and $\mathrm{DH}$ : diabatic heat processes.

BRAMS-40 analyses were used to analyze the right hand terms of Equations 1 and 2 and identify the processes dominating the local variation of vorticity and potential temperature, at each of the stages of the COL lifecycle. This methodology was applied in the 1980s by Sugi and Kanamitsu (1982) to estimate the advection of vorticity. Other authors used it to assess dynamic and thermodynamic processes (Lau and Lau (1992), Vera and Vigliarolo (2000) and Possia (2002), among others). Temporal derivatives were approximated by centered differences in 1-hour intervals.

To estimate tropopause folding and the entrance of stratospheric air into the troposphere the potential vorticity was calculated in isentropic coordinates $\left(\mathrm{PV}_{\theta}\right)$ given its conservative nature in adiabatic and frictionless processes. $\mathrm{PV}_{\theta}$ expressed in pressure coordinates (Bluestein, 1992) is

$$
P V_{\theta}=-g\left[\left(\frac{\partial v}{\partial x}-\frac{\partial u}{\partial y}\right)+f+\frac{R}{\sigma P}\left(\frac{\partial v}{\partial p} \frac{\partial T}{\partial x}-\frac{\partial u}{\partial p} \frac{\partial T}{\partial y}\right)\right]_{p} \frac{\partial \theta}{\partial p}
$$

where $\sigma$ is the static stability parameter, $R$ is the ideal gas constant

$\mathrm{PV}_{\theta}$ is always negative in the southern hemisphere and its magnitude is greater in the stratosphere than in the troposphere due to the sudden strengthening of the vertical gradient of potential temperature. Therefore, high values of $\mathrm{PV}_{\theta}$ at upper tropospheric levels indicate the presence of stratospheric air, because the atmosphere is approximately adiabatic and frictionless at upper levels, except in convective areas (Hoskins et al, 1985).
The World Meteorological Organization (1986) defined dynamic tropopause as the one that separates stratospheric from tropospheric air from, setting a $\mathrm{PV}_{\theta}$ value of $-1.6 \times 10^{-6} \mathrm{~K} \mathrm{~kg}^{-1}$ $\mathrm{m}^{2} \mathrm{~s}^{-1}=-1.6$ PVU (Potential Vorticity Units). However, some authors use values ranging from -1 to -2 PVU.

\section{RESULTS AND DISCUSSION}

Godoy et al (2011) presented a detailed analysis of the lifecycle of a cut-off low and showed that cyclonic circulation peaked at middle and upper tropospheric levels (about $300 \mathrm{hPa}$ during almost the entire COL lifecycle).

Figure 1 shows the Hövmöller diagram for relative vorticity at $300 \mathrm{hPa}$ from GDAS data and BRAMS-40 analyses. The comparison reveals that both the spatial location of the system and the duration of each of the stages are well represented in the BRAMS-40 analyses. Cyclonic vorticity in the mature stage (Figure 1b, 0000 UTC 29 March) is slightly stronger in the simulation, maybe because horizontal resolution is finer. The model was able to simulate accurately the time when the COL reached maximum cyclonic vorticity: 0600 UTC 27 March and 0000 UTC 29 March. Given that BRAMS40 analyses provide a good simulation of the COL lifecycle, those analyses were used to study the processes driving the system's lifecycle.

\subsection{Dynamic and thermodynamic processes}

In general, during the entire lifecycle of the COL, HVA and DT were of the order of $10^{-9} \mathrm{~s}^{-2}$ while the order of the remaining processes was $10^{-10} \mathrm{~s}^{-2}$. The joint effect of planetary vorticity advection, vertical advection of relative vorticity and tilting was assessed by examining LOT, which was defined as the sum of those processes. The latter definition made it possible to quantify the joint effect of those minor terms on the local variations of relative vorticity.

Horizontal and vertical advection of potential temperature in the thermodynamic equation is of the order of $10^{-4} \mathrm{~K} \mathrm{~s}^{-1}$. Diabatic heat reaches that order of magnitude over centralwestern Argentina where storms of varying intensity develop (Godoy et al, 2011).

Initial stage: (1800 UTC 24 March to 1800 UTC 26 March) The upper level trough precursor of the COL moved to the northeast and deepened (see Figure 1 in Godoy et al, 2011). Figure 2 shows the HVA, DT and LCV, and Figure 3 shows the AHT, AVT and VLT. Both figures represent values observed at 1200 UTC 26 March, 6 hours prior to the end of the initial stage and show the dominance of HVA (Figure 2a), with negative values, arranged in a band shape, downstream of the trough and positive values upstream. The local variation of vorticity, 

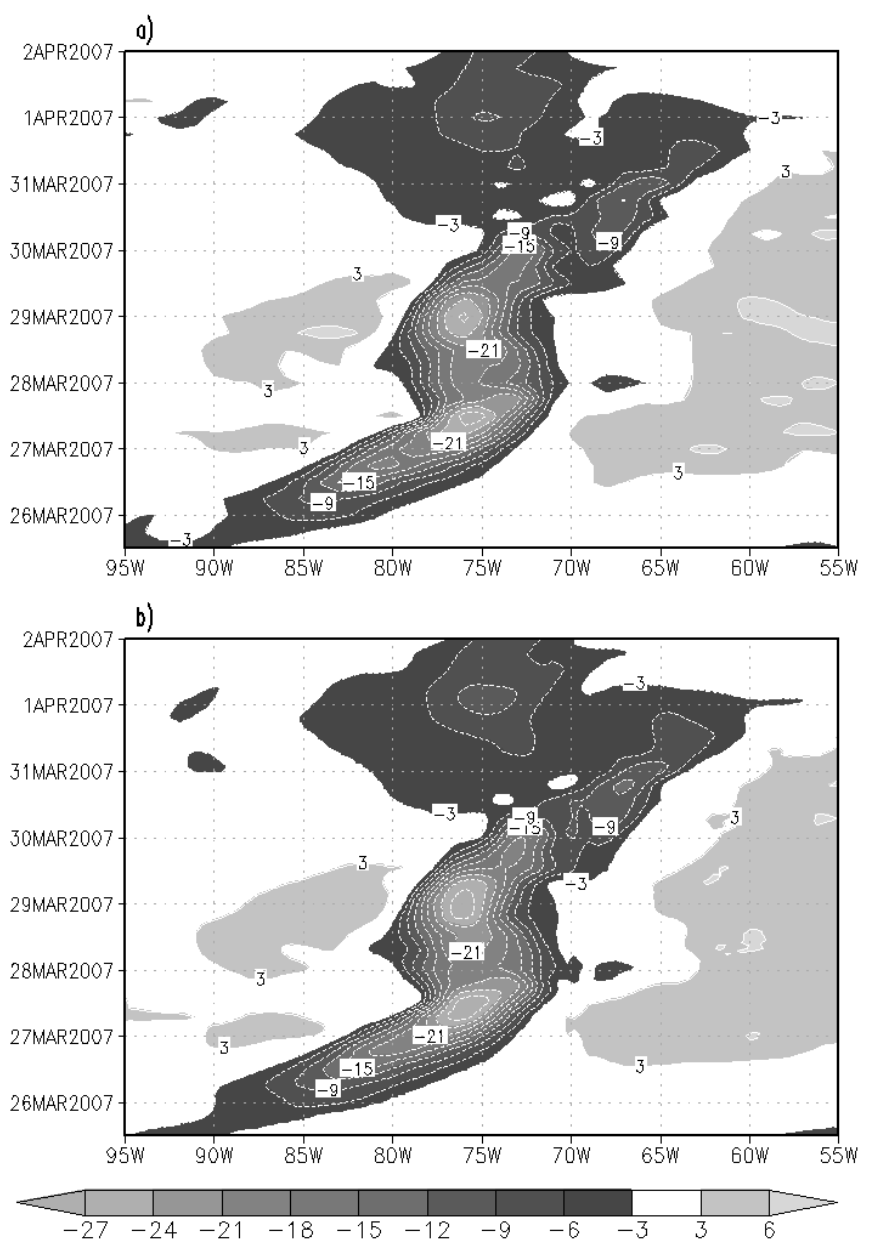

Figure 1: Hövmöller diagram of relative vorticity $\left(\mathrm{s}^{-1} \times 10^{5}\right)$ at $300 \mathrm{hPa}$ averaged between $37^{\circ} \mathrm{S}$ and $28^{\circ} \mathrm{S}$ : a) GDAS b) BRAMS-40

Figure 2c, shows the strong dominance of the HVA upstream and downstream of the trough axis. HVA and DT processes balance out over the axis of the trough (Figure 2).

AVT is opposite to the warm AHT over the coast of Chile and the cold AHT north of the trough axis (Figures 3a and 3b). At middle levels, LCV bands coincided with warming upstream and cooling downstream of the trough (Figures $2 \mathrm{c}$ and $3 \mathrm{c})$. During the initial stage, the enhancement of anticyclonic HVA on the polar side of the trough caused the axis to tilt in the NW-SE direction. This coincided with the amplification and southward progress of the ridge located upstream of the system (see Figure 2 a,b,c in Godoy et al, 2011). Worth highlighting is the dominance of warm advection in the Pacific Ocean south of $40^{\circ} \mathrm{S}$, which strengthens the mid- and upper level ridge (Figure 3).

Cut-off stage: This stage lasted 48 hours, and can be divided into two substages. In the first 18 hours (1800 UTC 26
March to 1200 UTC 27 March) the system continued moving slowly to the NNE, reaching maximum intensification (Figure 1). During this substage, temperature rise was noticeable at mid-levels west and south of the trough (Figure 4c 1200 UTC $27 \mathrm{March})$. Local variation of temperature responded to both horizontal and vertical advection (Figure $4 a$ and $4 b$ ). This temperature rise led to enhancing the geopotential trend, giving place to the cut-off of the low-pressure system. Figure 5a (1200 UTC), HVA presented well-defined positive and negative peaks in the northwest and northeast parts of the COL respectively. These are associated with the wind peak over that region as shown in Figure 4a in Godoy et al, 2011. Convergence and divergence effects of ageostrophic components (Figure $4 \mathrm{~b}$ in Godoy et al, 2011) associated with those wind peaks were opposite to the $\mathrm{AVH}$, resulting in a lower trend of relative vorticity (Figure $5 \mathrm{c}$ ). Therefore, in this substage, the cut-off process involved warm AHT and anticyclonic HVA to the south of the trough which enclosed cold air and formed a closed low pressure center.

Figure 6 shows the vertical cross sections of LCV, HVA, DT, LOT at the latitudes and on the days where those processes peaked. The left panel - 1200 UTC 27 March- shows that HVA and DT peaks were between the 200 and the $300 \mathrm{hPa}$ levels, with opposite sign. A stronger anticyclonic HVA between 500 and $300 \mathrm{hPa}$ upstream of the COL center showed the relevance of this process in the upper troposphere. On the other hand, DT and LOT oppose the effect of horizontal advection. In this substage, the pattern of local vorticity variation was dominated by HVA between the 600 and $200 \mathrm{hPa}$ levels.

From 1800 UTC 27 March to the end of the cut-off stage (1800 UTC $28 \mathrm{March}$ ), the COL remained quasi-stationary (with its center at $32^{\circ} \mathrm{S}-75^{\circ} \mathrm{W}$ approximately). During this substage HVA at $300 \mathrm{hPa}$ was weaker because of the closed circulation and a weak horizontal shear (Figures $3 \mathrm{~d}, 3 \mathrm{e}$ and $4 \mathrm{a}$ in Godoy et al, 2011). The central column in Figure 6 shows the vertical cross sections at 0000 UTC 28 March. The pattern of local vorticity variation at this time was opposite (though weaker) to the one of the previous hours. This coincided with the slight retrograde motion of the system at the end of this stage. At upper levels, DT dominated, while at middle levels LOT effects were partially offset with the HVA. In this case the effect of the sum of the higher order terms was noticeable in the vorticity tendency field.

Mature stage: (1800 UTC March 28 - 0000 UTC March 29) Cyclonic vorticity peaked and local vorticity variation decreased markedly. During this brief stage, HVA and DT were opposite in the area of the COL, which indicates that both processes are balanced (Figure 7). Thermodynamic processes also show a balance between the AVT and the AHT over the entire region (Figure 8). Significant values of LOT at mid-levels 
a) HVA

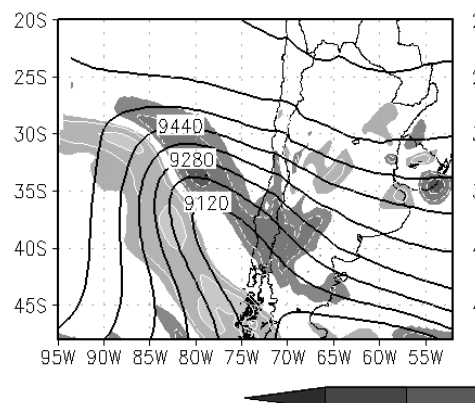

b) DT

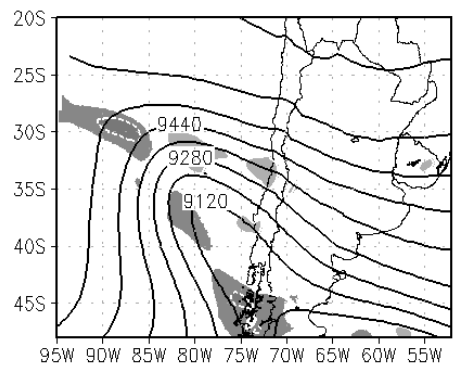

c) LCV

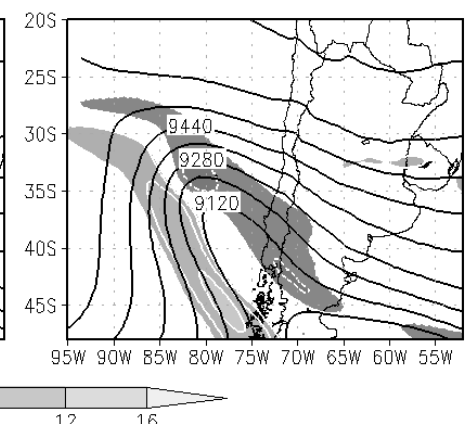

Figure 2: Processes involved in the evolution of vorticity $\left(\mathrm{s}^{-2} \times 10^{9}\right.$, shaded) and geopotential height at $300 \mathrm{hPa}$ (lines) at 1200 UTC 26 March: a) horizontal advection, b) divergence term, c) local variation of vorticity.

a) HAT

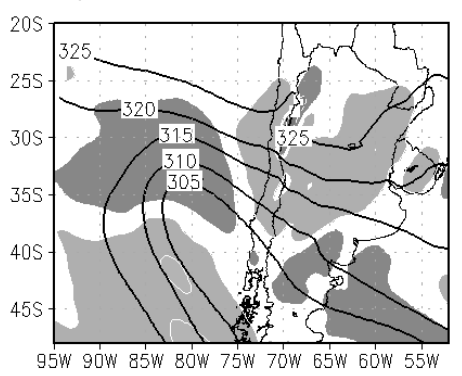

b) VAT

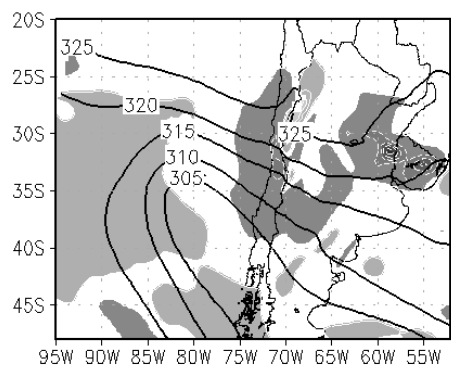

c) LVT

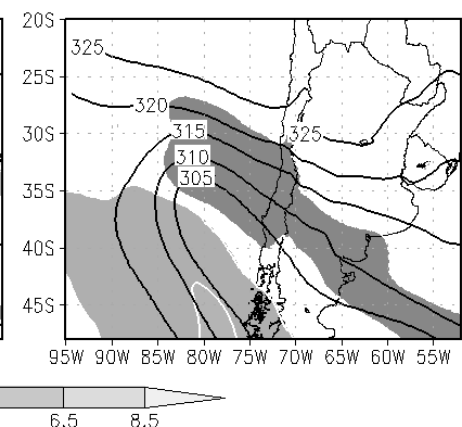

Figure 3: Processes involved in the evolution of temperature $\left(\mathrm{K} \mathrm{s}^{-1} \times 10^{4}\right.$, shaded) and potential temperature $(\mathrm{c} / 5 \mathrm{~K})$ at $500 \mathrm{hPa}$ (lines) at $1200 \mathrm{UTC}$ 26 March: a) horizontal advection of potential temperature, b) vertical advection of potential temperature, c) local variation of potential temperature.

a) HAT

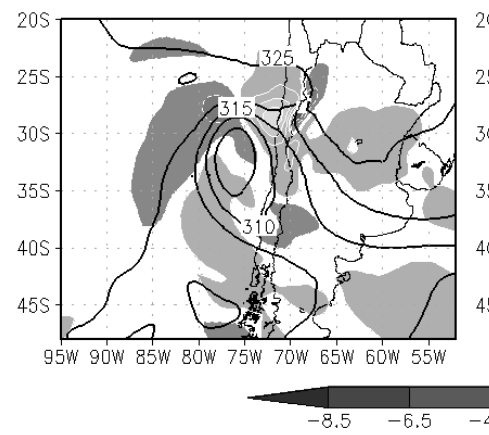

b) VAT

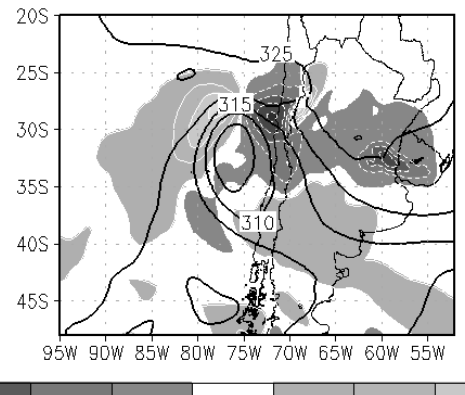

c) LVT

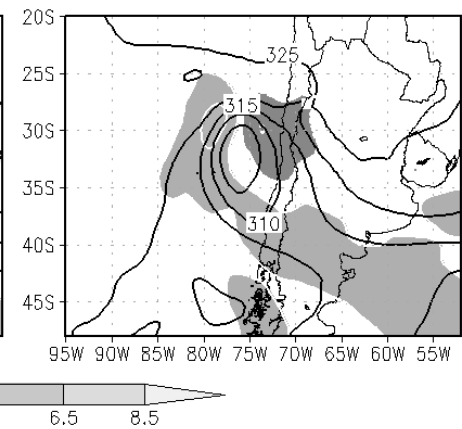

Figure 4: Idem Figure 3 at 1200 UTC 27 March.

(particularly to the west of the system) and of DT (between the 200 and $300 \mathrm{hPa}$ levels) started to appear at the end of the mature stage. The combination of these processes explains the stagnation of the COL windward of the Andes.

Decay stage: During the first hours of the decay stage (0600 UTC 29 March - 0000 UTC 31 March), the system at 300 hPa moved eastward and weakened. The right panel in Figure 6 shows the dominance of anticyclonic vorticity advection over the DT and lower order processes between the 400 and $200 \mathrm{hPa}$ levels.

The peak of cyclonic vorticity associated to the system began weakening gradually as it moved towards the continent. This coincided with a local variation of anticyclonic vorticity in the vicinity of the western area of the COL center (Figure 9c), primarily in response to HVA (Figure 9a). Figure 10c 
a) HVA

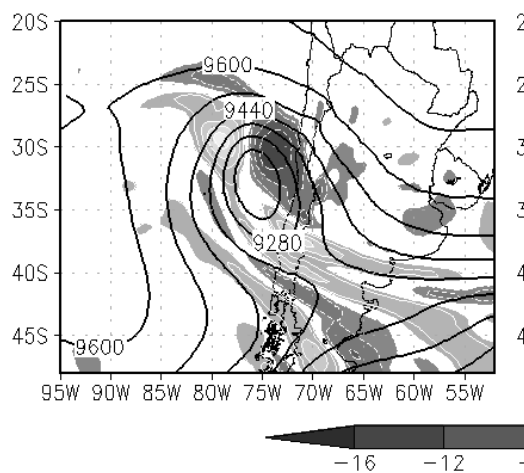

b) $\mathrm{DT}$

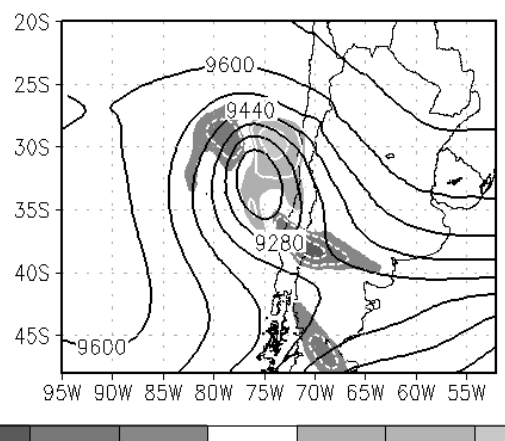

c) LCV

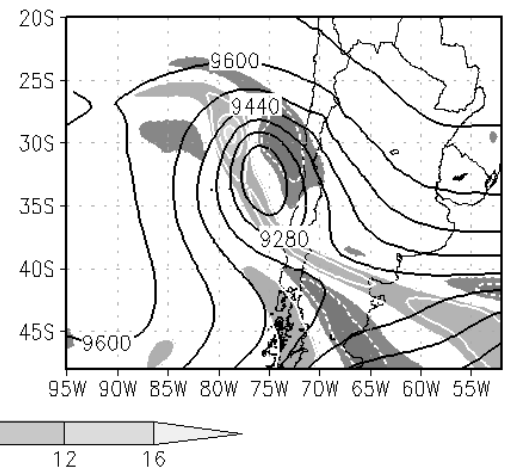

Figure 5: Idem Figure 2 at 1200 UTC 27 March.

shows a remarkable weakening of temperature variations with slight dominance of warm vertical advection to the west of the system (Figure 10b) that contributed to its weakening of the system. Cooling in the east of the system was caused by both advections.

\subsection{Entrance of stratospheric air into the troposphere in the $\mathrm{COL}$ region}

To complete the three-dimensional analysis of the $\mathrm{COL}$, the evolution of the $\mathrm{PV}_{\theta}$ was analyzed to assess the joint effect of the mass and motion fields in determining the dynamic tropopause. Shapiro $(1976,1978)$ and Keyser and Shapiro (1986) presented a complete observational analysis of the exchanges of tropospheric and stratospheric air in relation with the descent of the tropopause. Cox et al (1997) and Rondanelli et al (2002), among others, showed that the COL could be associated to the entrance of stratospheric air into the troposphere.

Figure 11 shows the Hövmöller diagrams of $\mathrm{PV}_{\theta}$ at upper levels averaged between $37^{\circ}$ and $28^{\circ} \mathrm{S}$. At $300 \mathrm{hPa}$ (Figure 11a) there are two peaks of cyclonic $\mathrm{PV}_{\theta}$, with the greatest intensification between 0000 UTC and 1200 UTC 27 March. Figure $11 \mathrm{~b}$ shows the penetration of stratospheric air crossing the $400 \mathrm{hPa}$ surface. The greatest intrusion took place in the first COL intensification period, as can be seen in Figure 1 and in Figure 6a in Godoy et al, 2011. The horizontal field of $\mathrm{PV}_{\theta}$ at $300 \mathrm{hPa}$, associated with the end of that intensification (1200 UTC 27 March, Figure 12.a), shows a minimum of potential vorticity with values smaller than (-10) PVU. The same field at $500 \mathrm{hPa}$ (Figure 11.b) shows stratospheric air entering the middle troposphere in the periphery of the COL.

The vertical structure of the system in this period was analyzed through two vertical cross sections (Figure 12a). Figure 13a shows the zonal cross section at $33^{\circ} \mathrm{S}$, and Figure $13 \mathrm{~b}$ the meridional cross section at $75^{\circ} \mathrm{W}$. These figures show the descent of the dynamic troposphere in the COL area with values smaller than -4 PVU at $400 \mathrm{hPa}$, descent was more marked in the periphery of the COL, and greater on the north side of the system overcoming the $600 \mathrm{hPa}$ level, where a tongue of drier air was observed, following the $310 \mathrm{~K}$ isentropic surface. That dry air was also an indicator of an intrusion of stratospheric air (Cox et al. 1997). The $\mathrm{PV}_{\theta}$ values observed in this COL showed that the intrusion reached levels closer to surface than those documented in Rondanelli et al (2002). The shape of the $\mathrm{PV}_{\theta}$ in Figure 13 is similar to the one shown in Figure 9 in Shapiro (1980), where the intrusion of potential vorticity also coincided with higher ozone concentration in the troposphere.

Figure 13a shows that to the east of the COL, potential vorticity and specific humidity did not follow the isentropic surface. Clouds at upper levels in the periphery of the COL (not shown), indicated the presence of diabatic effects that caused potential vorticity to drop. BRAMS-40 analyses showed upward motion and horizontal wind speeds stronger than $40 \mathrm{~m} . \mathrm{s}^{-1}$, which indicated the action of mechanisms favoring the mixing of tropospheric and stratospheric air such as convective erosion in the tropopause or erosion associated with turbulence in the upper-level jet (Shapiro, 1976 and Price and Vaughan, 1993)

\section{CONCLUSIONS}

To study the dynamic and physical processes involved in the different stages of the COL lifecycle, BRAMS enriched analyses (BRAMS-40) were used to improve the temporal resolution of the GDAS analyses (four times a day).

The initial stage was dominated by HVA on both sides of the upper-level trough axis. The horizontal pattern of this 

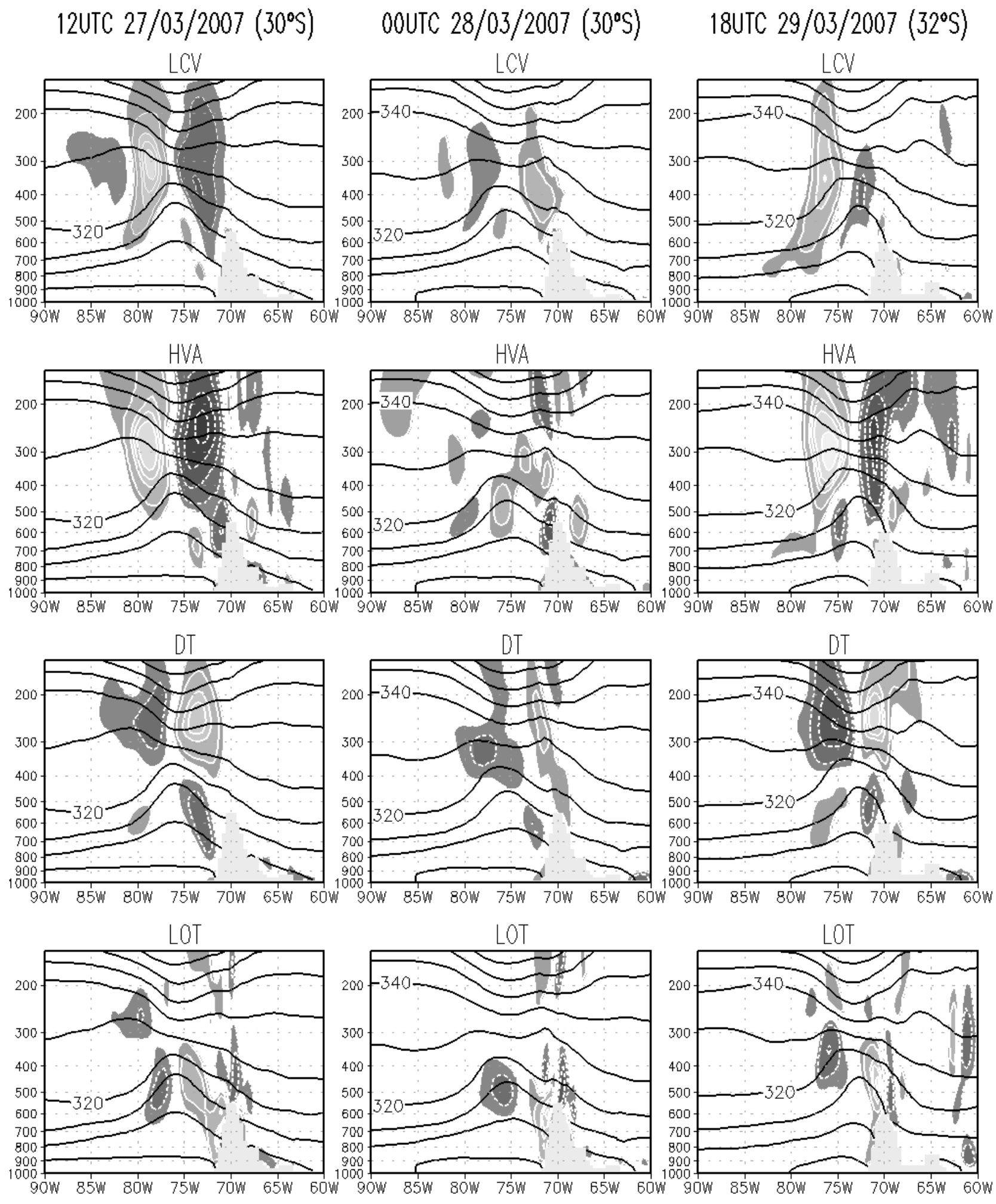

$-16-12$
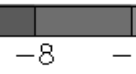

Figure 6: Vertical cross section of the processes involved in the evolution of vorticity $\left(\mathrm{s}^{-2} \times 10^{9}\right.$, shaded $)$ and potential temperature $(\mathrm{K}$, lines) at 1200 UTC the $27^{\text {th }}, 0000$ UTC the $28^{\text {th }}$ and 1800 UTC the $29^{\text {th }}$ March: a) local change of vorticity, b) horizontal vorticity advection, c) divergence effect and d) lower order terms. 
a) HVA

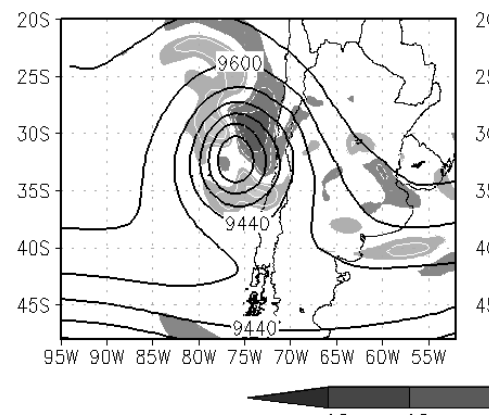

b) DT

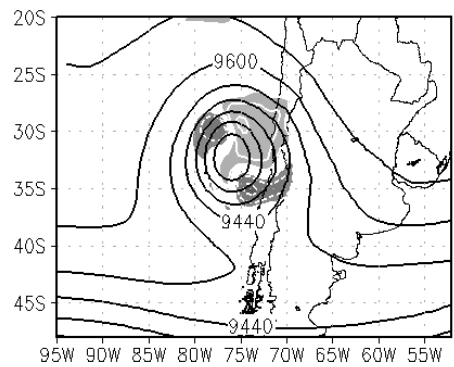

c) LCV

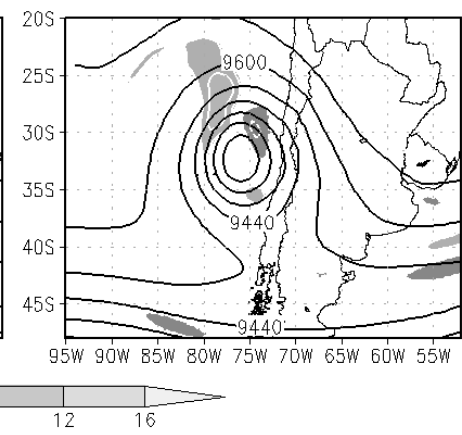

Figure 7: Idem Figure 2 at 0000 UTC 29 March.

0) HAT

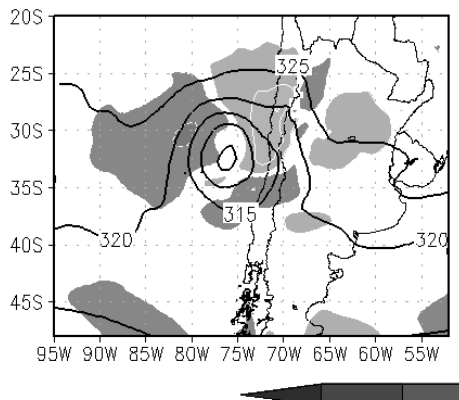

b) VAT

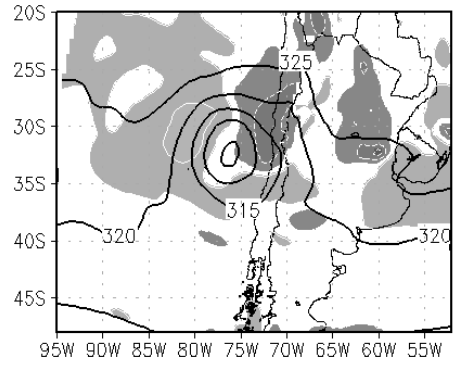

c) LVT

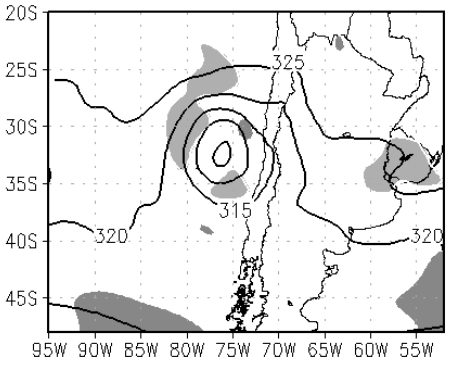

Figure 8: Idem Figure 3 at 0000 UTC 29 March.

a) HVA

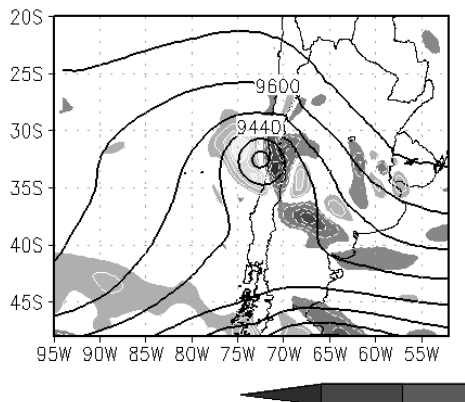

b) $\mathrm{DT}$

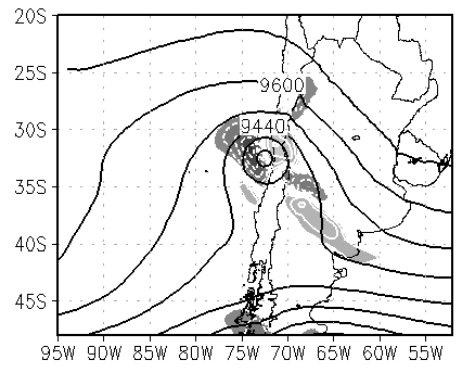

c) LCV

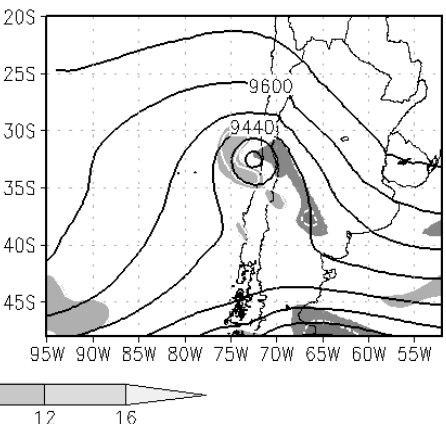

Figure 9: Idem Figure 2 at 0000 UTC 30 March.

a) HAT

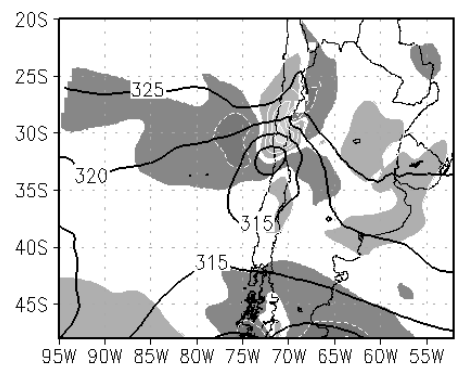

b) VAT

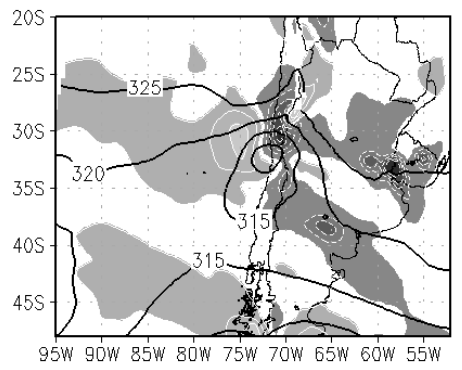

c) LVT

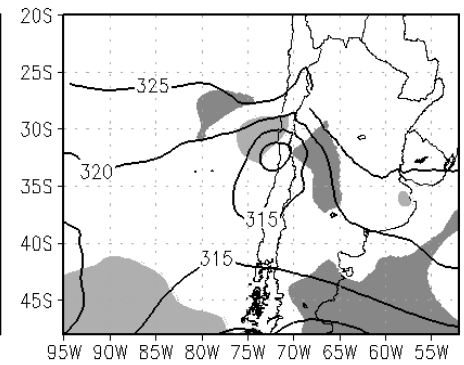

Figure 10: Idem Figure 3 at 0000 UTC 30 March. 


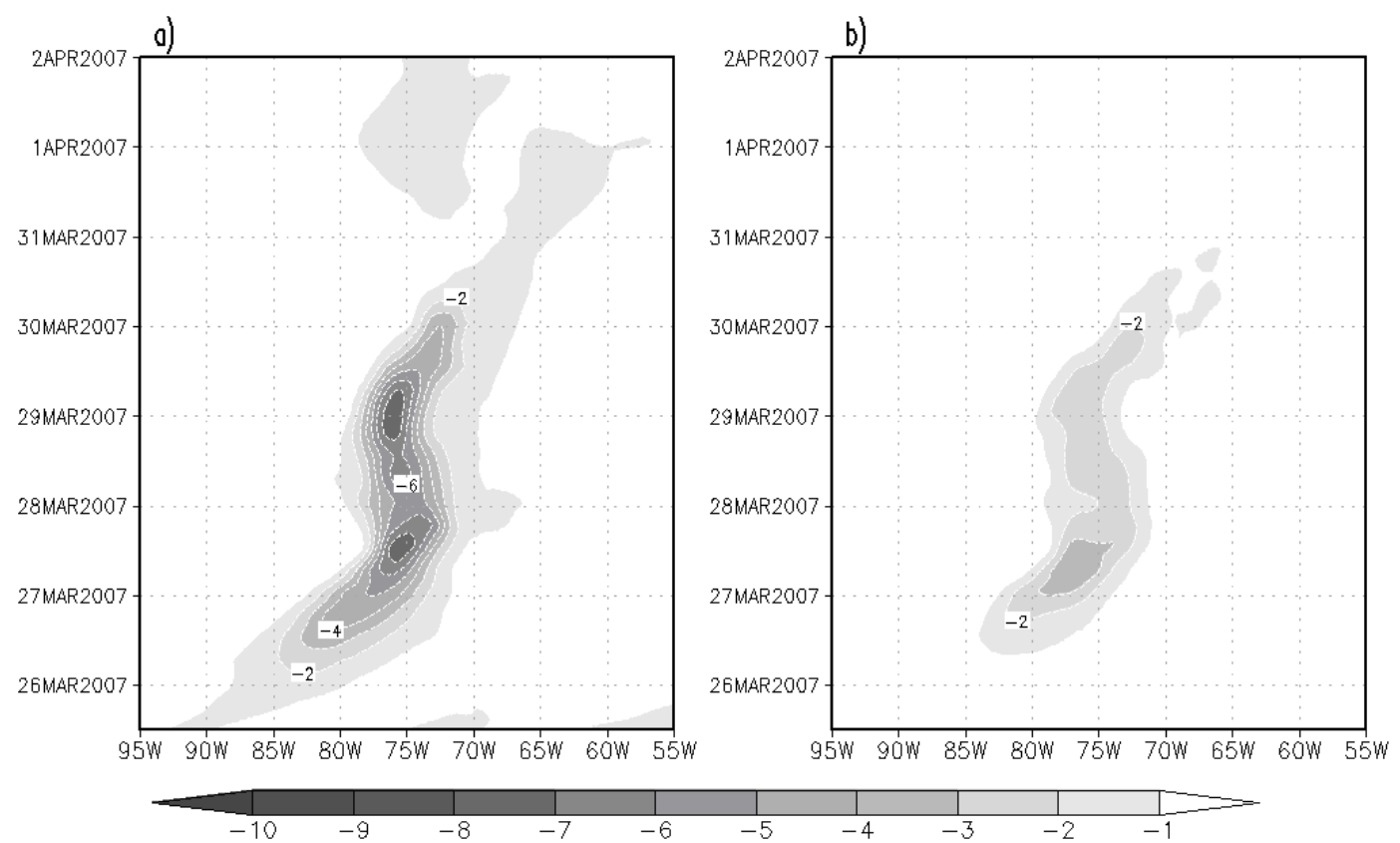

Figure 11: Hövmöller diagram of mean potential vorticity (PVU), between $37^{\circ}$ and $28^{\circ} \mathrm{S}$ at a) $300 \mathrm{hPa}$ and b) $400 \mathrm{hPa}$.

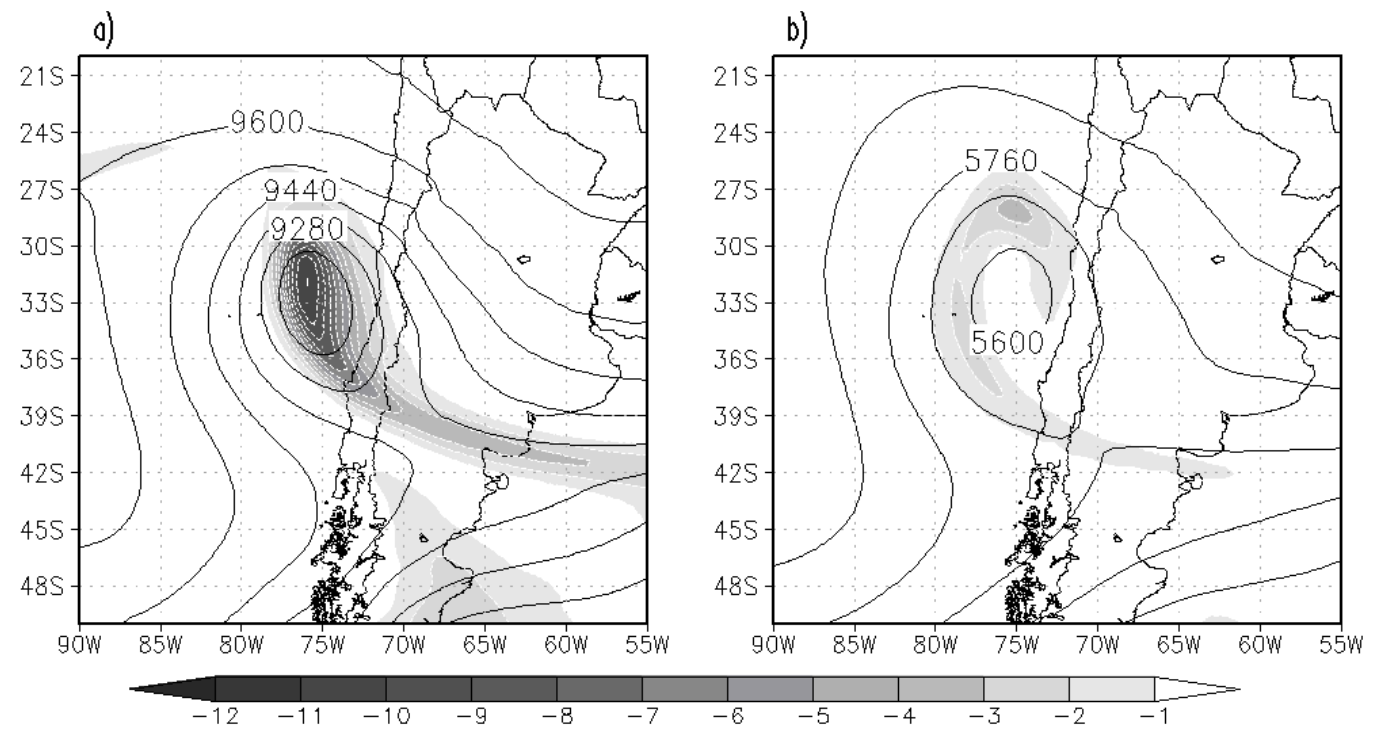

Figure 12: Potential vorticity (PVU, shaded) and geopotential height (mgp, cont) at $1200 \mathrm{UTC} 27 \mathrm{March}$ at: a) $300 \mathrm{hPa}$ and b) $500 \mathrm{hPa}$.

process forced the trough to move to the NE with the trough axis maintaining NW-SE direction. The mid level horizontal advection of temperature caused temperature cooling in the area of COL development, while warm advection dominated south of the system, strengthening the ridge upstream.

In the first 12 hours of the cut-off stage (1800 UTC $26 / 3$ to 1800 UTC $27 / 3$ ), HVA dominated, coincident with the greatest intensification of the COL. Horizontal advection of warm anticyclonic vorticity in the South Pacific and Patagonia, was responsible for the cut-off of the cyclonic center from its polar source.

In the mature stage, the eastward motion of the system decreased and reversed for 12 hours under the dominance of DT, while the local variation of vorticity decreased in the area of the COL. After that, the system remained stationary due to the balance between DT and HVA. 


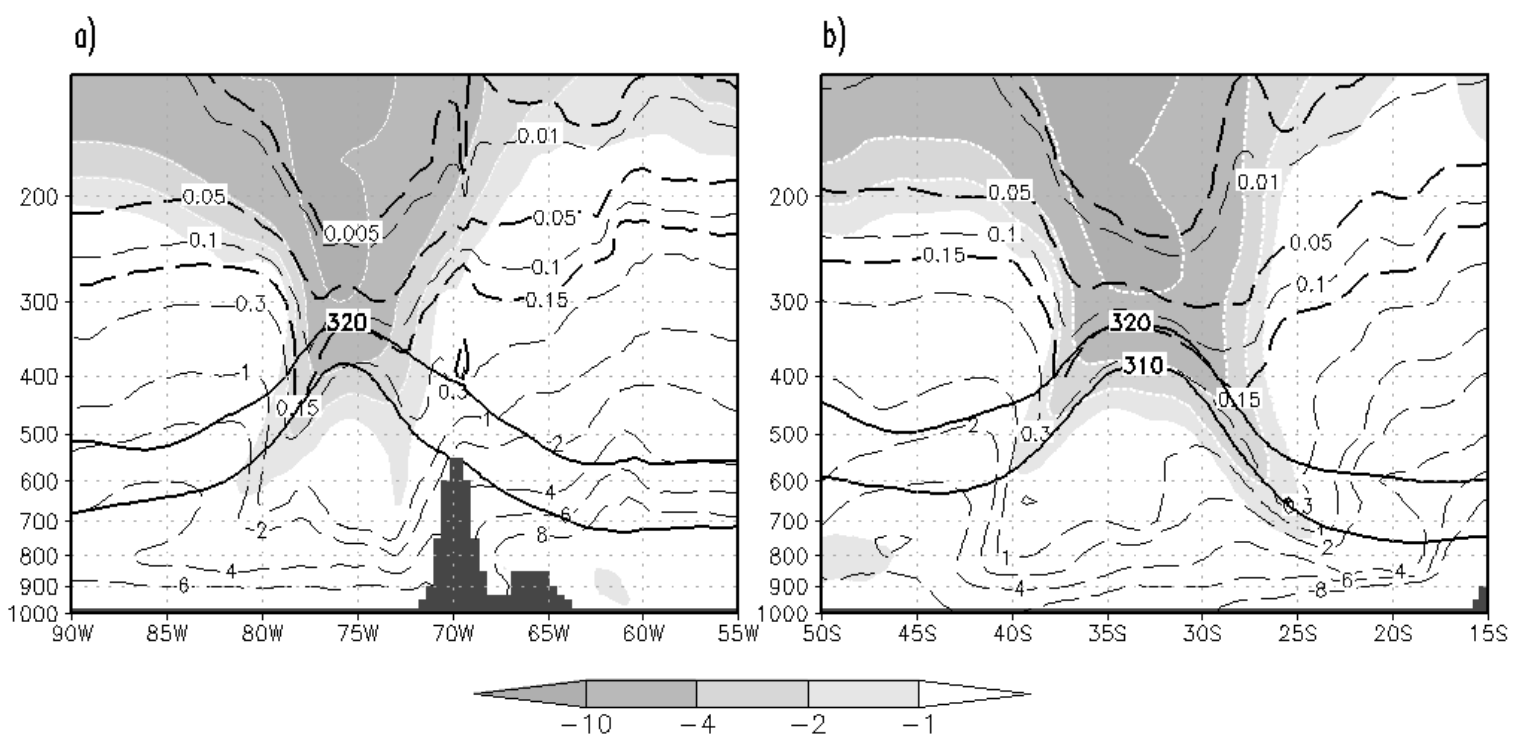

Figure 13: Potential vorticity (PVU, shaded), specific humidity (g/kg, dashed line) and potential temperature (K, black contour) at $1200 \mathrm{UTC} 27$ March: a) section at $33^{\circ} \mathrm{S}$ and b) at $75^{\circ} \mathrm{W}$.

Vertical advection of temperature had greatest influence during the decay stage, because it caused the warming and weakening of the system.

The evolution of the dynamic tropopause was examined to complete the three-dimensional study of the COL. The results show that the tropopause descended to $450 \mathrm{hPa}$ in the center of the system during the cut-off stage. On the east and west sides of the COL the descent of stratospheric air was even greater, reaching $700 \mathrm{hPa}$ in the descending branch downstream of the system. Specific humidity responded similarly to potential vorticity, which confirms that stratospheric air was entering the troposphere.

This paper identified the dynamic and thermodynamic processes acting in the different stages of the lifecycle of a cut-off low. Although cut-off lows have common features, their behavior is difficult to forecast (Saucedo, 2010). More cases need to be studied in order to be able to characterize cut-off lows.

\section{ACKNOWLEDGEMENTS:}

This research was supported by CONICET PhD scholarship granted to Alejandro Godoy and post-PhD scholarship granted to Yanina García Skabar, UBACyT grants X478, X159, 20020090200607 and ANPCyT grant 200700355. BRAMS simulations were performed using the computer facilities of the mesoscale modeling group (CIMA(CONICET/ UBA)-DCAO(UBA).

\section{REFERENCES}

BELL, G.; BOSART, L. A case study diagnoses of the formation of an upper-level cutoff cyclonic circulation over eastern United States. Monthly Weather Review, v. 121, p. 16351655. 1993.

BLUESTEIN, H. B. Synoptic-Dynamic meteorology at midlatitudes, Volume I. New York: Oxford University Press. 1992.

BORQUE, P.; SALIO P.; NICOLINI, M.; GARCÍA SKABAR, Y. Environment Associated with Deep Moist Convection under SALLJ Conditions: ACase Study. Weather and Forecasting, v. 25, p. 970-984, doi: 10.1175/2010WAF2222352.1. 2010

CAMPETELLA, C. M.; POSSIA, N. E. Upper-level cutoff lows in southern South America. Meteorology and Atmospheric Physics, v. 96, p. 181- 191, 2007.

CAMPETELLA, C.; GODOY, A.;SAUCEDO, M. Relación entre las bajas segregadas y la precipitación en el sur de Sudamérica. In: CONGREMET X y CLIMET XIII, 10, 2009, Buenos Aires. Anales... Buenos Aires: Editora, 2009. $1 \mathrm{CD}-\mathrm{ROM}$

CHEN, C.; COTTON, W. R. A one dimensional simulation of the stratocumulus-capped mixed layer. Boundary-Layer Meteorology, v. 25, p. 289-321. 1983.

COX, B. D.; BITHELL, M. Y.; GRAY, L. J. Modelling of stratospheric intrusions within a mid-latitude synoptic-scale disturbance. Quarterly Journal Royal Meteorological Society, v. 123, p. 1377-1403. 1997. 
FREITAS, S. R.; LONGO, K. M.; SILVA DIAS, M. A. F.; CHATFIELD, R.; SILVA DIAS, P.; ARTAXO, P.; ANDREAE, M. O.; GRELL, G.; RODRIGUES, L. F.; FAZENDA, A.; PANETTA, J. The Coupled Aerosol and Tracer Transport model to the Brazilian developments on the Regional Atmospheric Modeling System (CATTBRAMS). Part 1: Model description and evaluation. Atmospheric Chemistry and Physics, v. 9, p. 2843-2861. 2009.

FUNATSU,N. M.; GAN, M.A; CAETANO, E. A case study of orographic cyclogenesis over South America. Atmósfera, v. 17, p. 91-113. 2004.

GARCÍA SKABAR,Y.; NICOLINI M. Enriched Analyses with Assimilation of SALLJEX Data. Journal of Applied Meteorology and Climatology, v. 48, p. 2425-2440, doi: 10.1175/2009JAMC2091.1. 2009.

GARREAUD, R. D.; FUENZALIDA H. A. The influence of the Andes on Cutoff Lows: a modeling study. Monthly Weather Review, v. 135, p. 1596-1613. 2007.

GODOY, A.; CAMPETELLA C.; POSSIA N. Un caso de baja segregada en el sur de Sudamérica: descripción del ciclo de vida y su relación con la precipitación. Revista Brasileira de Meteorologia, v.26, n.3, 491 - 502, 2011.

GRELL, G. A. Prognostic evaluation of assumptions used by cumulus parametrizations. Monthly Weather Review, v. 121, p. 764-787. 1993.

GRELL, G. A.; DEVENYI, D. A generalized approach to parameterizing convection combining ensemble and data assimilation techniques. Geophysical Research Letters, v.29, n. 14, 1693. 2002.

HOSKINS, B. J.; MCINTYRE; M. E., ROBERTSON, A. W. On the use and significance of isentropic potential vorticity maps. Quarterly Journal Royal Meteorological Society, v. 111, p. 877-946. 1985.

KEYSER, D.; SHAPIRO, M.A. A review of the structure and dynamics of upper-level Frontal Zone. Monthly Weather Review, v. 114, p. 452-499. 1986

LAU, K. H.; LAU, N. C. The energetics and propagation dynamics of tropical summertime synoptic-scale disturbances. Monthly Weather Review, v. 120, p. 2523-2539. 1992.

MELLOR G. L.; YAMADA T. Development of a turbulence closure model for geophysical fluid problems. Reviews of Geophysics and Space Physics, v. 20, p. 851-875. 1982.

NICOLINI, M.; GARCÍA SKABAR, Y. Diurnal cycle in convergence patterns in the boundary layer east of the Andes and convection. Atmospheric Research, v. 100, n. 4, p. 377-390. 2011.

PIZARRO, J.; MONTECINOS, A. Cutoff cyclones off the subtropical coast of Chile. SIXTH INTERNATIONAL
CONFERENCE ON SOUTHERN HEMISPHERE METEOROLOGY AND OCEANOGRAPHY, 4, 2000, Santiago de Chile. Preprints, p. 278-279.

POSSIA, N. An explosive cyclogenesis over land. Atmósfera, v. 15, p. 1-19. 2002.

PRICE, J. D.; VAUGHAN, G. The potential for stratospheretroposphere exchange in cut-offlow systems. Quarterly Journal Royal Meteorological Society, v. 119, p. 343-365. 1993. QUISPE, N.; AVALOS, G. Intense snowstorm in the southern mountains of Peru associated to the incursion a cut-off low pressure system at upper level. Proceedings 8th ISHCMO, 4, 2006, Foz do Iguaçu, Anais... Brasil: Editora, 2006. 1 CD-ROM

REYNOLDS, R. W.; RAYNER N. A.; SMITH T. M.; STOKES D. C.; WANG W. An Improved In Situ and Satellite SST Analysis for Climate, Journal Climate, v. 15. 2002

RONDANELLI, R.; GALLARDO, L.; GARREAUD, R. Rapid changes in ozone mixing ratios at Cerro Tololo $\left(30^{\circ} 10^{\prime} \mathrm{S}\right.$, $70^{\circ} 48^{\prime} \mathrm{W}, 2200 \mathrm{~m}$ ) in connection with cut-off lows and deep troughs. Journal of Geophysical Research, v. 107(D23), 4677, doi:10.1029/2001d001334. 2002.

SAKAMOTO K.; TAKAHASHI M. Cut off and Weakening Processes of an Upper Cold Low. Journal of the Meteorological Society of Japan, v. 83, p. 817-834. 2005.

SAUCEDO, M. Bajas segregadas en el sur de Sudamérica: validación de dos modelos numéricos de pronóstico. 2010. 117 p. Tesis (Licenciado en Ciencias de la Atmósfera) Departamento de Ciencias de la Atmósfera y los Océanos, Universidad de Buenos Aires, 2010.

SHAPIRO, M.A. The rol of turbulent heat flux in the generation of potential vorticity in the vicinity of upper-level jet stream systems. Monthly Weather Review, v. 104, p. 892-906. 1976.

SHAPIRO, M.A. Further evidence of mesoscale and turbulent structure of upper level jet stream-frontal zone systems. Monthly Weather Review, v. 106, p. 1100-1111. 1978.

SHAPIRO, M.A. Turbulent mixing within tropopause folds as a mechanism for the exchange of chemical constituents between the stratosphere and troposphere. Journal of Atmospheric Science, v. 37, p. 994-1004. 1980.

SMAGORINSKY, J. General circulation experiments with the primitive equations. Part I, The basic experiment. Monthly Weather Review, v. 91, p. 99-164. 1963.

SOUZA, E. P.; SILVA E. M. Impacto da Implementação de uma Parametrizaçao de Convecçao Rasa em um Modelo de Mesoscala. Descriçao e Testeo de Sensibilidade do Esquema. Revista Brasileira de meteorologia, v.18, p. 33-42. 2002. SUGI, M.; KANAMITSU, M. A Study of a Subtropical Upper Level Cyclone Using JMA Operational Forecast Model. Journal of the Meteorological Society of Japan, v. 60, p. 932-945. 1982. 
TRIPOLI, G. J.; COTTON W. R. The Colorado State University three dimensional cloud/mesoscale model- 1982. Part I: General theoretical framework and sensitivity experiments. Journal de Recherches Atmospheriques, v. 16. p. 185220. 1982.
VERA, C. S.; VIGLIAROLO, P. K. A Diagnostic Study of Cold - Air Outbreaks over South America. Monthly Weather Review, v. 128, p. 3-24. 2000. 